\title{
Iban as a koine language in Sarawak
}

\author{
CHONG SHIN
}

\begin{abstract}
This article attempts to delineate the issue of linguistic homogeny in Iban variants in Sarawak (Malaysia). In brief, the Iban speakers are claimed to descend from Upper Kapuas watershed, Western Kalimantan (Indonesia). Based on local traditions and oral materials, this ethnic group began to move out from Kapuas watershed and penetrate into Sarawak in sixteenth century. After several generations, they expanded to become the major ethnic group in the state. Several recent studies show that the number of ethnic Ibans in West Kalimantan is fairly small and the distribution of Iban communities often displays a pattern of distant pockets or enclaves. The purpose of this article is to explain how a minority group became a majority ethnic group in a newly settled territory. This article argues that this research question is strongly related to the ethnonym of "Iban" and regional dialect levelling or koineization. During the initial stage of the migration, the term "Iban" was an exonym. By the mid-twentieth century, the exonym "Iban" or "Sea Dayak" was gradually becoming an endonym. The change in the status of this ethnonym has enlarged the population size of the "Iban" in Sarawak. The existence of several Iban-like ethnic groups in Sarawak, for example, the Balau, Remun, Kantu', Milikin, and Kumpang, adds support to this argument. This article revisits the issue of linguistic homogeny of the Iban language, taking the language koineization approach. A phonological analysis on the Ibanic varieties spoken in West Kalimantan offer a possible explanation that the Iban variants in Sarawak have appeared as a stable linguistic variety as a result of "dialect levelling" and "simplification". Furthermore, the development of koine Iban seems to fulfil several features in the koine developmental continua proposed by J. Siegel (1985).
\end{abstract}

KEYWORDS

Iban; Ibanic; migration; koine; dialect levelling.

CHONG SHIN, PhD, Associate Professor. He is currently a lecturer and Senior Research Fellow at Institut Alam dan Tamadun Melayu (ATMA), Universiti Kebangsaan Malaysia. His fields of interest are dialectology and sociolinguistics, particularly the Austronesian and Sinitic languages in Western Borneo and Sarawak. His publications include Bahasa dan masyarakat di Lembangan Sungai Saribas (2019, Kuala Lumpur: Dewan Bahasa dan Pustaka) and Bahasa Ibanik di Borneo Barat (2019, Kuala Lumpur: Dewan Bahasa dan Pustaka). Chong Shin can be contacted at: chongshin@ukm.edu.my.

(C) 2021 Faculty of Humanities, Universitas Indonesia

CHONG SHIN | DOI: 10.17510/wacana.v22i1.985. 


\section{INTRODUCTION}

This article introduces a discussion of the koineization of the Iban language - the lingua franca of Sarawak (Malaysia); see Map 1.

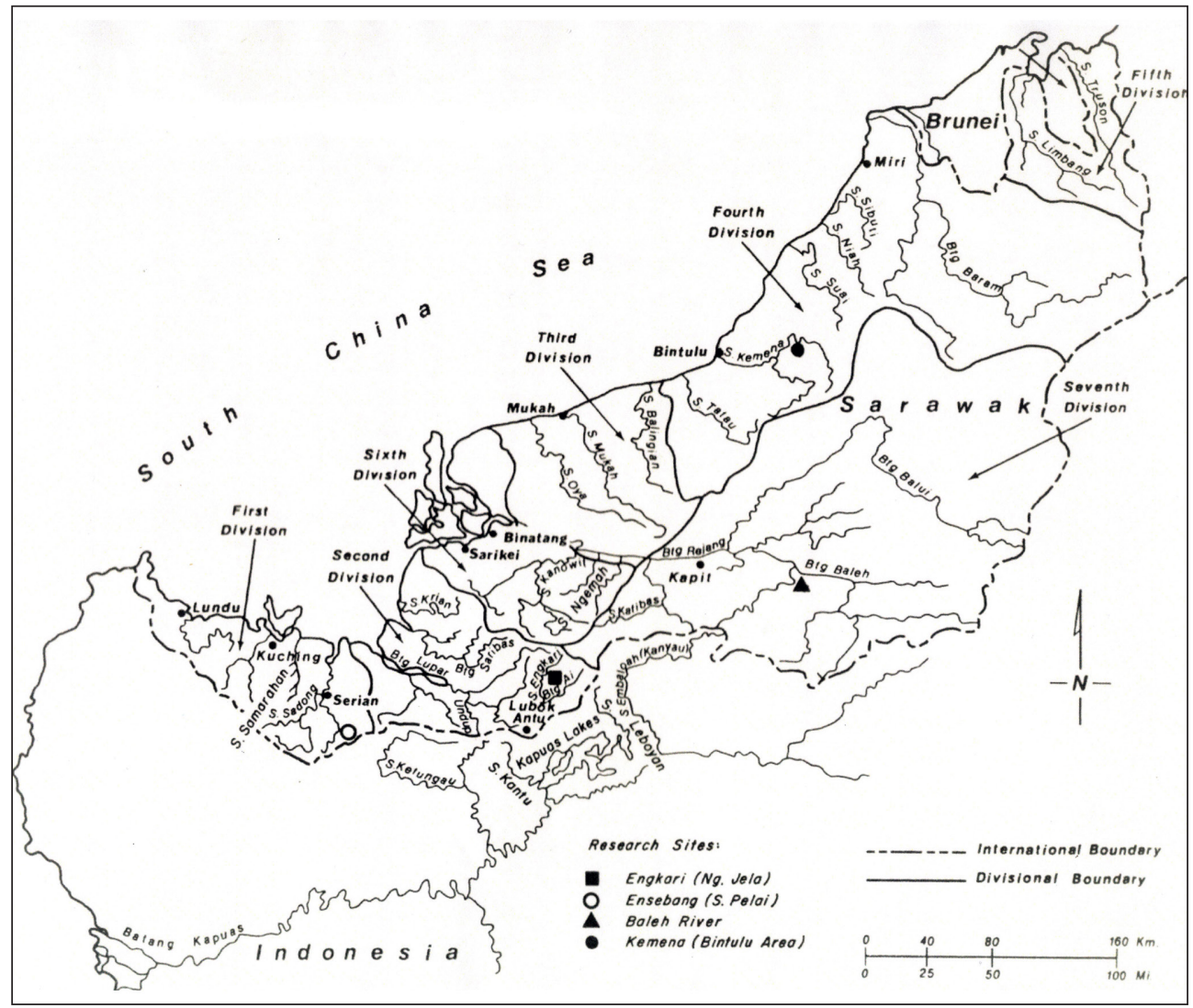

Map 1. Sarawak (Malaysia) and Kapuas Valley (Indonesia) (C. Padoch 1982: 2).

Iban is a dominant language in the state and is spoken by over 30 percent of the Sarawak population, either as their first language or as second or third languages (James T. Collins 2002). A remarkable feature of this language is that it displays linguistic homogeny in the variety spoken in the western, central, and northern regions and even hundreds of kilometres into the interior. Several previous linguistic studies carried out by Asmah Haji Omar (1981), Rahim Aman (1997), Chong Shin and James T. Collins (2019) corroborate this statement. The oral histories of the Iban and their genealogies recount that the Iban in Sarawak came down from Upper Kapuas watershed, Western Kalimantan (Padoch 1982). The term "Ibanic" was first coined by A.B. Hudson (1970: 306): "[...] members of an Ibanic sub-group, comprising isolects such as Sebuyau, Mualang, Kantu', Seberuang, and the various related Iban dialects of Sarawak and Brunei, may be easily identified on the basis of the presence in word-final position in certain lexical forms of /-ai/ where cognates in other Malayic dialects exhibit /-an/, /-ang/, or, less frequently, /-ar/". 
The linguistic characteristics of these varieties are more closely related to the "Iban" language in Sarawak than they are to Malay dialects. Within the Malayic language family, K.A. Adelaar (1992) classifies Ibanic in the sub-group of Malayic which includes Iban, Kantu', Mualang, Bugau, Ketungau, Desa, Seberuang, and other languages. Nevertheless, his study does not propose any internal sub-grouping of Malayic languages. In a recent study, A.D. Smith (2017) has classified Iban and Ibanic as the Western Borneo Malayic sub-group language. Communities which speak languages and dialects closely related to Iban can also be found in significant numbers in West Kalimantan.

\section{Previous Literature}

The Iban form the most populous Dayak group in Western Borneo (C. Sather 2016) and in Sarawak. This ethnic group is by no means unstudied. A number of studies have looked into the history of Iban migration and expansion. Nearly all previous studies have claimed that the Iban ethnic group in Western Kalimantan is the ancestor of the Iban community in Sarawak. Using oral sources, B. Sandin (1968) has plotted the early migration route of the Iban from Kapuas watershed to western areas in Sarawak. He claims that the Iban began to cross the Kapuas Hulu Range - at present the international border line between Western Kalimantan (Indonesia) and Sarawak (Malaysia) - into Sarawak in the middle of the sixteenth century. These pioneers were believed to have arrived in the Batang Lupar drainage-basin and settled along the Undop River. Within the span of five generations, they migrated to the north, east, and west, occupying the tributaries of the Saribas, Batang Sadong, Batang Layar, and Batang Lupar. In 1800s, the Ibans began moving into the basin of the Rejang River from the headwaters of the Batang Lupar, Saribas River and the Katibas River (a tributary of the Rejang River). By 1870, it was reported that large numbers of Iban had settled along the Oya and Mukah Rivers. These pioneers kept expanding, reaching the Balingian, Tatau, and Kemena (Bintulu) Rivers in the early twentieth century. In 1900s, the Iban reached the Baram Valley and Limbang River in the northern part of Sarawak.

The migration and expansion of the Iban into Sarawak is also described at length in the research carried out by R. Pringle (1970). Most of the data used in this book are taken from the materials collected by Sandin - a well-known Iban historian and curator of the Sarawak Museum from December 1966 to March 1974. Pringle (1970: xiv) admits this in the introduction: "In the course of research I rely heavily on Benedict Sandin's advice and assistance in many ways [...] local traditions and other oral materials [in this book] are mostly collected by Mr. Sandin over the course of many years [...]". Therefore, his book gives a good insight into the Iban expansion, especially into the northern part of Sarawak before the arrival of the First Rajah (James Brooke). It also mentions the growth of the Iban population in Sarawak. In 1939, the Iban population was 167,700 and, twenty years later, this population had attained a high rate of growth and increased to 490,585. Sather (2016) states that there are over 700,000 Iban in present-day Sarawak and a smaller number, estimated at 
14,000 , continue to live in West Kalimantan. During the last century, the Iban also migrated northwards from Sarawak to neighbouring Brunei Darussalam and Sabah. Yet others, many of them labour migrants, now live in Peninsular Malaysia). Map 2 (by Pringle 1970: 248) is the map of early Iban expansion in Sarawak over a span of approximately two decades.

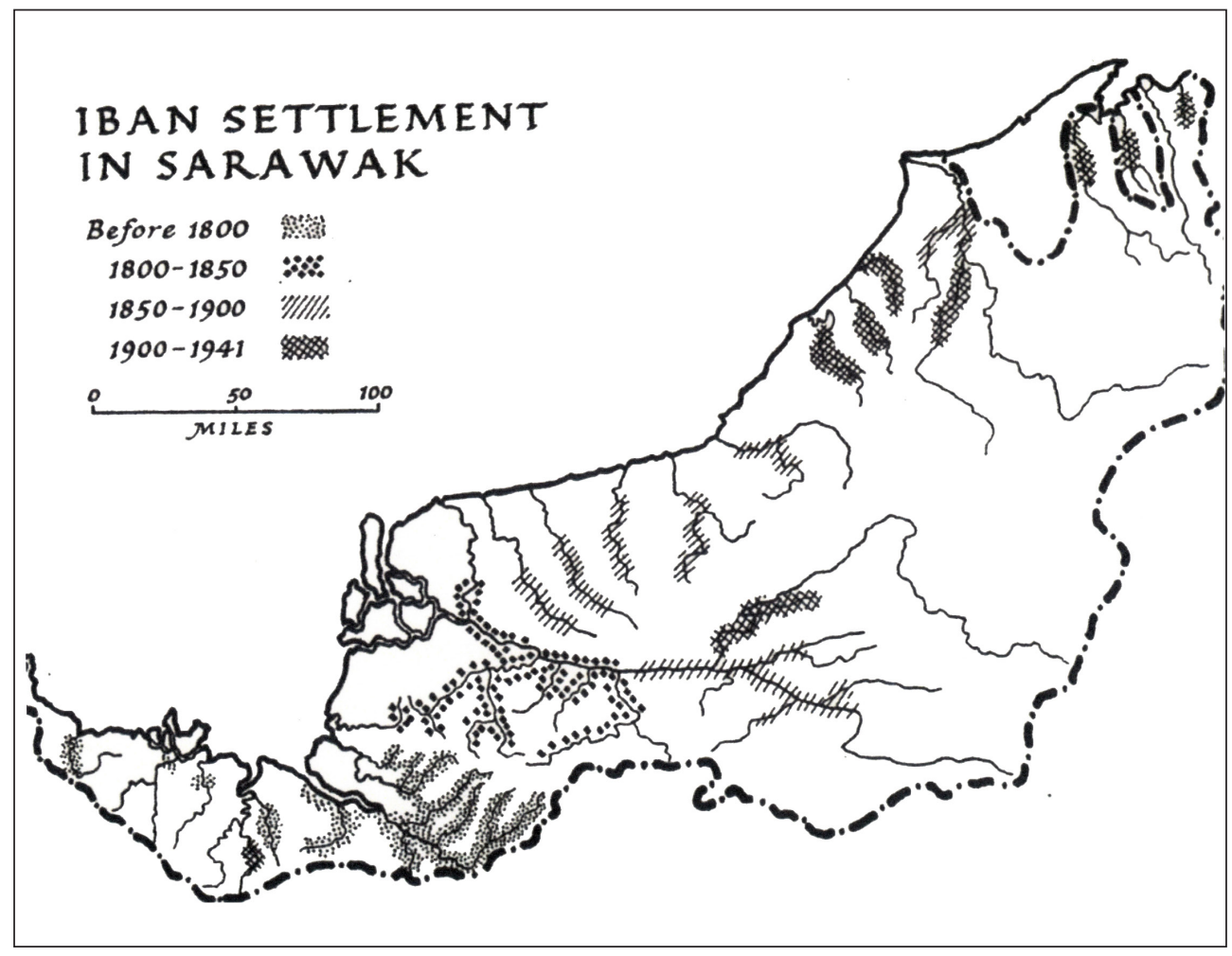

Map 2. The expansion of Iban in Sarawak (Pringle 1970: 248).

The migration of the Iban into Sarawak is also discussed in an article by V. King (1976). It investigates the contact between the Iban and the Mbaloh in terms of material culture, but also outlines the movement of Ibans into the Batang Lupar via the nearby Kapuas Lakes, the Leboyan, and Mbaloh Rivers of West Kalimantan, and later to the Rejang Basin. His principal research aim is to concentrate how to redress the balance by synthesizing and analysing material about Iban migration and their culture contact with the Mbaloh in West Kalimantan. In his article he also refers to Sandin's (1968) work on Iban migration. In a study carried out by Padoch (1982), the same sources were again used in a monograph which describes the historical, demographic, technological, and other adjustments made by the Iban in response to their changing environmental conditions. Basing himself on the study carried out by Sandin, Padoch conducted intensive field research in the Engkari, the Kemena, and Upper Ensebang Basins as a follow-up to exploring the Iban migration history in Sarawak. 
In an article about when the Iban first began to take an interest in beads and beading, M. Heppell (2020) also mentions the Ibanic speakers' migration history in Western Kalimantan. By tracing and analysing the inventories of the textile patterns favoured by the Ibanic speakers (Mualang, Kantu', Desa, and Iban), Heppell (2020:3-4) states that, "their textiles share a number of common design features indicating that these features were developed before the Ibanic split into individual groups". He also argues that, if they all shared a common heritage, it was probably acquired while they were still living together. The internal split was believed to have occurred during the fourteenth century, not long after the attacks by the troops of the expanding Majapahit Empire and the aftermath of an epidemic. The Mualang headed south and arrived in the Belitang area; the Kantu' moved up to the Kapuas; the Desa settled in the vicinity of Sintang; and the Iban entered the Merakai area and thence into Sarawak. The Ibanic speakers who settled down in Sungkung were believed to have migrated up to the Kapuas Lakes, into the Leboyan and Mbaloh River basins, eventually reaching the Batang Ai', Katibas River, and Baleh River in Sarawak.

For more than a decade, researchers have realized and acknowledged the existence of Ibanic varieties in Western Kalimantan, Indonesia. Collins (2004: 34) has noted that: "[...] a hundred year ago, Enthoven (1903) observed that the Mualang language with certain differences in pronunciation and intonation belonged to the same language group as Rambai, Kantu', Ketungau, Belabang, and Seberuang in Kalimantan, as well as Batang Lupar (in Kalimantan and Sarawak), and Undop, Katibas, Saribas, and Lemanak in Sarawak". ${ }^{1}$ P.D. Dunselman (in King 1978: 59), a Capuchin monk, also notes that: "There exist strong cultural relations between these [Mualang] Dayak and the Iban of Batang Lupar in Western Borneo and Sarawak, and likewise with other groups of the central Kapuas area, particularly the groups of the Kantu', the Seberuang, and the Desa, and the various groups of the Ketungau basin, namely the groups of the Bugau, Tabun, and Banyur. Remarkable similarities are to be observed in their language, in their techniques of weaving, plaiting, and in their myths".2

In fact, in the past forty years, there has been a remarkable increase in the number of research studies about the Ibanic languages in West Kalimantan. For example, Michael R. Dove (1988) has studied the ethnolinguistics of the Kantu'; Yoseph Thomas et al. (1992) produced a monograph on Kantu' grammar; Rahim Aman (1997) undertook a comparative study of Iban, Mualang, and Kantu'; Reed Wadley (1994) has written extensively about the Iban communities in Indonesia; Collins (2004) describes the nomenclature, distribution, and characteristics of the Ibanic languages in West Kalimantan; Chong (2008) has studied the Ibanic varieties spoken in Ketungau and the Belitang Valley, and also edited a book about the Ibanic varieties in West Kalimantan (2019).

\footnotetext{
${ }^{1}$ For further details, see J.J.K. Enthoven (1903).

2 See also Dunselman (1955).
} 
In fieldwork conducted with funding from the Southeast Asia Studies Regional Exchange Program (SEASREP) project, I have been able to identify the ethnonyms, varieties, and distribution areas of Ibanic in West Kalimantan (Table 1).

\begin{tabular}{|l|l|}
\hline Ethnonym / Ibanic varieties & Distribution areas \\
\hline Kantu' & Upper Kapuas \\
\hline Ketungau (Sebaru', Demam) & Ketungau River \\
\hline Mualang & Belitang River \\
\hline Seberuang & Seberuang and Suhaid Rivers \\
\hline Desa & Sintang \\
\hline Bugau & Kalimantan-Sarawak border \\
\hline Iban & Sentarum Lake \\
\hline
\end{tabular}

Table 1 . The Ibanic ethnonym, varieties, and distribution areas in West Kalimantan.

Before the era of the Rajah Brooke rule in Sarawak (from 1841), the term "Iban" was an exonym: the name of an ethnic group created by another group of people. Initially, this term was not in general use either by the Brooke government or by the Iban pioneers themselves. They normally identified themselves by river, for example: "We of the Skrang", "We of the Rejang", and sometimes by territory, "We of this area". The most popular mythology to explain the word "Iban" is that it is believed to have originated from a corruption of Kayan word, hivan, which means 'wanderer'. This word was used by the Kayans of the Rejang headwaters as a term of contempt for the pioneers whose restless disposition made them unpleasant neighbours (Pringle 1970). Since the upper waters of the Rejang are Kayan territory, accordingly the term "Iban" remained popular only in this limited area and was not known by any other Dayaks until the mid-1800s. All the non-Malays pagan tribes have often been indiscriminately classified together under the name Dyaks or Dayaks (C. Hose and W. McDougall 1966). Owing to their perceived ferocity and their aggressive culture of waging war against sea-dwelling groups and the emerging Western trade interests in the eighteenth and nineteenth century, James Brooke, the first Rajah of Sarawak, coined the term "Sea Dayak" for the "Iban" to differentiate them from the hill/land Dayaks (or Bidayuh). Consequently, the name "Iban" has been generally adopted by the Sea Dayaks. Since World War II, this term has been accepted by the Ibans in Sarawak. Before then, for many years neither Brooke nor the Ibans accepted the word "Iban" (Pringle 2007).

Reviewing these explanations, it can be stated that the unadorned semantic meaning of "Iban" was 'wanderer'. This term later underwent a semantic shift and became an endonym and was also adopted as a self-designated name for other minority ethnic groups in Sarawak (especially the ethnic groups linguistically and culturally related to the Iban). Several lines of evidence show the existence of these marginal groups in Sarawak: 
(i) The existence of an "Iban" sub-group, namely Balau on the lower Sadong and its eastern tributaries; see Padoch (1982). This sub-group was recruited as an ally by James Brooke in an attack on the Skrang Iban in 1844 (V.H. Sutlive 1992).

(ii) Padoch (1982) also reports that there was a group of immigrants, comprising about seven households, of Iban from the Sering and Kantu' districts, Western Kalimantan. According to Collins (2004) and Yusriadi (2019), the Kantu' variety exhibited minor differences to the Iban variant in pronunciations.

(iii) Pringle (1970) reported that there is an "unknown" group, Milikin, which is alleged to be neither Bidayuh nor Iban, but "appear to fall mid-way between these two great families in total culture".

(iv) Pringle (1970) reports that a feud once broke out between the people of Kumpang and the Iban in the headwaters of Engkilili, Sarawak. Chong's (2019) study found that Ketungau River in West Kalimantan is the distribution area of the Kumpang speakers.

(v) The Remun in Serian, Sarawak, known as "Iban Remun" on account of their language codes are approximately 88 percent cognate to the Iban. Peter H. Cullip (2000) labelled this isolect "a dialect of Iban"; see also Chong Shin and Remmy anak Gedat (2019).

The fact that the "Iban" language in Sarawak is composed of different varieties has been pointed out elsewhere in previous studies. For example, Hose and McDougall (1966: 33) mention that: "All the Sea Dayaks speak one language with but slight local diversities of dialect". J.J. Ray (1913: 7-8) on the other hand reported that: "[...] the Ulu Ai (the same as the Katibas) have the same language with a harsher pronunciation. The Engkaris differ only in respect to the letter $r$ which they cannot pronounce, and for which they substitute $h$, as bahoh for baroh. In the languages of the Undops, Sebuyaus, and Balohs there are slight dialectic differences". Just as the ethnonym "Iban" shifted to become an endonym, compounded by the fact that most previous studies rely entirely on Sandin's (1968) source, the dialectical differences in "Iban" have largely been ignored. The assertion that the Iban language landscape in present-day Sarawak was formed by the dispersal of ethnic Iban from West Kalimantan should be revisited. As noted in Collins (2004), the population of ethnic Iban in West Kalimantan is rather small, so it is debatable "how this minority ethnic group can form a strong demographic profile in Sarawak just after a few generations?"

\section{KOINE AND KOINEIZATION}

The term koine originates from Greek and means 'common', referring to the variety of Greek which became the lingua franca or common language of the eastern Mediterranean during the Hellenistic period. This Greek koine was based mainly on the Attic dialect but had linguistic features of other regional dialects such as Ionic. However, it was less complex in certain 
areas of phonology and morphology than any contributing dialect. It was spoken mainly as a second language dialect but, in some areas, it did have communities of native speakers. Eventually it was standardized, used for writing and as the official language of the Macedonian empire (G. Thomson 1960 in Siegel 1993). According to Siegel (1993), the term koine has been applied to designate dialects which have emerged in immigrant communities after different social or regional dialects of transplanted languages have come into contact in a new environment. It is a stable linguistic variety which results from contact between varieties which are sub-systems of the same linguistic system. Functionally, it originally serves as a lingua franca among speakers of the contributing varieties but later can become a primary language.

In brief, scholars who have contributed to koine studies are H. Blanc (1968), V. Bubenik (1993), R. Mesthrie (1993), R. Amery (1993), J. Siegel (1985), P. Kerswill and A. Williams (2005), and J.D. Spence (2013). Blanc (1968) was the first person who used the term koine to refer to the result of the convergence of Israeli Hebrew. He gives a detailed account of the development of Israeli Hebrew and describes this language as a koine forged from "a variety of literary dialects, several substrata, and several traditional pronunciations" with no particular dialects which are "dominant and available". Bubenik (1993) traced the pre-koine, dialect mixing and levelling simplification, stages of development, and the contact with other language which forged the Greek koine; Mesthrie (1993) examined the mixed origins of South African Bhojpuri, persisting idiolectal variation and the importance of demographic factors in koineization; Amery (1993) presented a detailed linguistic and socio-linguistic information on Dhuwaya koine, a koine which emerged from contact between various clan dialects in Northeast Arnhem Land; Siegel (1985) explored the koine language of Fiji Hindi and analysed the formation of this new dialect through the processes of dialect levelling, mixing, and simplification. Kerswill and Williams (2005) presented the case of Milton Keynes, an English new town designated in 1967. They found that the formation of a new dialect was conducted by older children and the dialect levelling was more rapid in a new town than in an old-established town. Spence's (2013) dissertation explores the Pacific Coast Athabaskan languages (northwestern California and southwestern Oregon) diachronically and extrapolates how these languages are related to each other and to the Athabaskan language family, the social and structural dynamics of dialect contact between Athabaskan varieties from the mid-nineteenth to the mid-twentieth century, and the linguistic consequences of bilingualism as Athabaskan communities shifted from their heritage languages to English.

To sum up, koineization is a process which leads to the mixing of linguistic sub-systems, that is of language varieties which are either mutually intelligible or share the same genetically related superposed language. It occurs in contexts of increase interaction and integration between the speakers of these varieties (Siegel 1985). P. Trudgill (1998 in P. Kerswill 2002) state that there are three stages of a new-dialect formation: 


$\begin{array}{ll}\text { Stages } & \text { Speakers involved } \\ \text { I } & \text { Adult migrants } \\ \text { II } & \text { First native-born speakers } \\ \text { III } & \text { Subsequent generations }\end{array}$

\author{
Linguistic characteristics \\ Rudimentary levelling \\ Extreme variability and further levelling \\ Focusing, levelling, and reallocation
}

According to Trudgill (1986), the koineization of a language is composed of three processes: mixing, levelling, and simplification. Mixing means the presentation of features from different input varieties. Levelling means the reduction of marked variants. "Marked" might refer to features with a limited geographical distribution in the country of origin which have been transplanted to the new territory (Kerswill 2002). Simplification in this context refers to the loss of marked categories from a language and their replacement by unmarked categories. A phonological system with fewer marked elements might legitimately be regarded as simpler (Trudgill 1986). The following section outlines the linguistic characteristics of the Ibanic varieties in West Kalimantan; before justifying the claim that the Iban language in Sarawak has also been subjected to this process.

\section{THE DIVERSIFICATION OF IBANIC VARIETIES}

This section emphasizes several distinguishing linguistic features demonstrated in Demam, Sebaru', Desa, Seberuang, Bugau, Mualang, Kantu', and Banjur in West Kalimantan. The areas of distributions, variants, and hamlets of these Ibanic variants are shown in Table 2.

\begin{tabular}{|l|l|l|}
\hline River areas & Hamlets & Varieties \\
\hline Ketungau & $\begin{array}{l}\text { Nanga Skepat } \\
\text { Tanjung Dak } \\
\text { Sungai Antu }\end{array}$ & $\begin{array}{l}\text { Demam } \\
\text { Sebaru' } \\
\text { Bugau }\end{array}$ \\
\hline \multirow{3}{*}{ Belitang } & $\begin{array}{l}\text { Ngelai } \\
\text { Nsaban } \\
\text { Temedak Merat }\end{array}$ & $\begin{array}{l}\text { Mualang } \\
\text { Seberuang } \\
\text { Banjur }\end{array}$ \\
\hline \multirow{2}{*}{ Kantu' $^{\prime}$} & $\begin{array}{l}\text { Selupai } \\
\text { Telutuk }\end{array}$ & Kantu' \\
\hline
\end{tabular}

Table 2. The distribution areas, hamlets, and variants of Ibanic in West Kalimantan.

The complexity of the Ibanic varieties in West Kalimantan, Indonesia can be summarized as follows:

i. The Seberuang and Desa variety indicate that the phoneme of $/ \mathrm{y} /$ in initial position appears as a voiceless onset [x]. For example, [xa:n] 'jaw' (Seberuang) and [u' $u^{x}$ yan] (Desa) 'person, other person'.

ii. Complex in diphthongs. The diphthongization of high vowel / i/ (for example, / kakiy/ 'leg' in common with other Ibanic varieties), appears as [kaka ${ }^{e} y$ in Sebaru' and as [kakey] in Seberuang. 
iii. The diphthongization coupled with centralization of final high vowels in Ketungau Sesat varieties in Sekadau. For example: [sikuw] and [kakiy] (Compare with [sikuw] and [kakiy] in the Desa, Seberuang, Mualang, and Bugau variety).

iv. Distinctive monophthongization features of vowel cluster in Bugau variety; for example, / au/ $\rightarrow$ [a], for example [taun] 'year' $\rightarrow$ [ta:].

v. The weakening of final velar nasal $/ \mathrm{y} /$, which is retained only as the nasalization of the preceding vowel, for example: 'return' is pronounced as [pulã:] in Ketungau Sesat whereas as [pulay] in other Ibanic varieties.

vi. The / $\mathrm{k} /$ and / $\mathrm{P} /$ which appears as distinct phonemes in most of the Ibanic varieties (for example, the minimal pairs like / kəya?/ 'the longtailed macaque' and /kəyak/ 'rice crust'). The / k/ and / $/$ apparently merged as / $\mathrm{P}$ in the dialects of Ketungau Sesat and Desa.

vii. In final syllable, $/ \mathrm{u} /$ in Mualang will be followed by an open back unrounded vowel [a], if the word final position consists of a glottal stop / ?/. If the word final position is $/ \mathrm{k} /$, the allophone of $/ \mathrm{u} / \mathrm{is}[\mathrm{o}]$. For example, [usuok] 'ribs' and [tindua?] 'sleep'.

viii. There are differences in the treatment of final consonants. Phoneme /s/ in the final position reflect as three different fricatives - the voiceless glottal fricative [h], the voiceless alveolar fricative [s], and the voiceless palatal fricative [ç]. For example, the word /manis/ 'sweet' appears as [manies] in Mualang, [manieh] in Bugau, and [manieç] in Demam and Sebaru.

\section{Phonological features of Iban languages in Sarawak}

This section discusses the common phonological features of Iban variants in Sarawak using data from four different areas in Sarawak, namely: Betong, Kapit, Sibu, and Bintulu. In short, five remarkable phonological features of the Iban Sarawak can be summed up:

1. The realization of $r$;

2. The /-ay/ diphthong;

3. Diphthongization of high vowels;

4. Contrast between $/ \mathrm{k} /$ and $/ \mathrm{r} /$; and

5. Allophones of $/-\mathrm{s} /$.

This article only pays attention to the phonological aspects because there are no noticeable differences in grammar between the Iban variants in Sarawak and the Ibanic variants in Western Kalimantan (based on my preliminary reviews; but further study is needed). For example:

(i) Speaking of the morphology, Rahim Aman (1997) observes that the verbal prefix \{bəkə\} existed in Iban variants in Sarawak and the Kantu' variety of Kalimantan. 
(ii) According to J. Tjia (2007: 147), Mualang is very similar to Iban in lexicon and structure, for example, in the prototypical transitive clause of Mualang. He states that, "the patient object always appears. All verbs that exhibit prototypical transitivity have to be marked with the prefix $N$ in the simple active-transitive clause (see 1$)$. With a verb marked by $N$ - the agent of the event is assigned the subject role in the clause. Otherwise the clause is ungrammatical (see 1a)". This feature can be identified as similar to the voice construction of the Iban variant in Sarawak, see Table 3.

Mualang (Tjia 2007)

$1 \quad$ Ku N-bunuh manuk.

1s ACT-kill chicken

'I killed a chicken.'

1a *Ku bunuh manuk. 1s ACT-kill chicken

'I killed a chicken.'
Padang anak Luna and Chemaline anak Osup (2011)

1 namiakna $\mathrm{N}$-bach bup charita.

Kid that ACT-read book story

'The kid is reading a story-book.'

1a *namiakna bacha bup charita.

Kid that ACT-read book story

'The kid is reading a story-book.'

Table 3. Mualang vs. Iban variant in Sarawak.

\subsection{THE REALIZATION OF * $\mathrm{r}$}

In the Betong, Kapit, and Bintulu variants (Table 4), the historical $r$ appears as a trill $[\mathrm{r}]$ in the initial and medial position of the word. Whereas this consonant appears as [h] in the Sibu variant. Most Iban varieties in Sarawak display the allophone [r]. The graph $<\mathrm{r}\rangle$ has therefore been selected in standard Iban orthography - a standardized Iban variant which is widely used in formal communication, mass media, education, and popular culture.

\begin{tabular}{|c|c|c|c|c|}
\hline Meaning & Betong & Kapit & Sibu & Bintulu \\
\hline house & rumeah & rumeah & humeah & rumeah \\
\hline human & ureay & ureay & uheay & ureay \\
\hline stomach & paruat & paruat & pahuat & paruat \\
\hline weed & rumpuat & rumpuat & rumpuat & rumpuat \\
\hline
\end{tabular}

Table 4. The realization of * $\mathrm{r}$.

\subsection{THE /-ay/ DIPHTONG}

The diphthong /-ay/ (Table 5) is a diagnostic feature of an Ibanic language (Hudson 1970). All the Iban data studied reflect this shift of PAN and protoMalayic*-an, -an, -ar >/-ay/. 


\begin{tabular}{|l|l|l|l|l|l|}
\hline Meaning & Betong & Kapit & Sibu & Bintulu & Earlier form \\
\hline big & basay & basay & bəsay & basay & *bosar \\
\hline to come & datay & datay & datay & datay & *datan \\
\hline to eat & makay & makay & makay & makay & *makan \\
\hline to return & pulay & pulay & pulay & pulay & *pulan \\
\hline to walk & bajalay & bajalay & bojalay & bajalay & *bojalan \\
\hline
\end{tabular}

Table 5. The /-ay/ diphthong.

\subsection{DiphthongIZATION OF HIGH VOWELS}

In general, Iban varieties in Sarawak display the diphthongization of the high vowels $/ \mathrm{u} /$ and /i/ in word-final position. In Table $6 a$ the final $/ \mathrm{u} /$ is diphthongized as [-uw], while in Table $6 \mathrm{~b} / \mathrm{i} / \mathrm{became}$ [iy].

\begin{tabular}{|l|l|l|l|l|l|}
\hline Meaning & Betong & Kapit & Sibu & Bintulu & Earlier form \\
\hline burn & tunuw & tunuw & nunuw & tunuw & *tunu \\
\hline I & akuw & akuw & akuw & akuw & *aku \\
\hline elbow & sikuw & sikuw & sikuw & sikuw & *siku \\
\hline louse & kutuw & kutuw & kutuw & kutuw & *kutu \\
\hline stone & batuw & batuw & batuw & batuw & *batu \\
\hline
\end{tabular}

Table 6a. Diphthongization: / u/ became [-uw].

\begin{tabular}{|l|l|l|l|l|l|}
\hline Meaning & Betong & Kapit & Sibu & Bintulu & Earlier form \\
\hline dream & mimpiy & mimpiy & mimpiy & mimpiy & *mimpi \\
\hline heart & atiy & atiy & atiy & atiy & *ati \\
\hline leg & kakiy & kakiy & kakiy & kakiy & *kaki \\
\hline male & la:kiy & lakiy & lakiy & lakiy & *laki \\
\hline to stand & diriy & diriy & dihiy & diriy & *diri \\
\hline
\end{tabular}

Table 6b. Diphthongization: /i/ became [-iy].

\subsection{CONTRAST BETWEEN / $\mathrm{k} / \mathrm{AND} / \mathrm{?} /$}

In most of the Malayic varieties spoken in Western Borneo, / k/ and / $/$ appear as distinct phonemes (Table 7). As a sub-group of Malayic, the Iban languages in Sarawak also exhibit (near-)minimal pairs contrasting / k/ and / ?/. 


\begin{tabular}{|l|l|l|l|l|}
\hline Meaning & Betong & Kapit & Sibu & Bintulu \\
\hline fat & lamak & lamak & lamak & lamak \\
\hline long (of time) & lama? & lama? & lama? & lama? \\
\hline long-tailed macaque & kəra? & kəra? & kəha? & kəra? \\
\hline rice husk & karak & karak & kəhak & karak \\
\hline
\end{tabular}

Table 7. / k/ and / $/$ / as distinct phonemes.

\subsection{Allophones of /-s/}

As described above, the consonant / s/ in the final position can occur as three different fricatives - the voiceless glottal fricative [h], the voiceless alveolar fricative [s], and the voiceless palatal fricative [ç] across the Ibanic varieties in West Kalimantan. However, the consonant /s/ in the Iban varieties of Sarawak appears as [s], for example, manies 'sweet' and putuas 'broke up'.

\section{IBAN AS A KOINE?}

The shifting of the term "Iban" from exonym to endonym in Sarawak has had an impact on Iban linguistic classifications. It would be a lamentable case of neglect if the homogeny of the Iban language throughout the state is simply asserted to constitute ordinary dialectic differences. This study claims that the Iban language in Sarawak is a koine language based on the observation that it fulfils the koine developmental continua proposed by Siegel (1985). In his research, Siegel outlined three stages in the developmental continuum of a koine language:

(i) The pre-koine or initial contact stage - initiated by an immigrant community; is the unstable stage; a continuum exists in which various varieties in contact are used concurrently and inconsistently; levelling and some mixing have begun to occur.

(ii) Stabilization - lexical, phonological, and morphological norms have been distilled from the various sub-systems in contact; a new compromise sub-system has emerged; besides intergroup communication, a stabilized koine can be extended to other areas. It can become a literary language or the standard language of a country; further linguistic expansion.

(iii) Nativization - a koine might become the first language for a group of speakers.

By reviewing the background of Iban migrations and the characteristics of the Iban language in Sarawak, this language is identified as fulfilling several features in the koine developmental continuum (Table 8). 


\begin{tabular}{|c|c|c|}
\hline Stages & Feature(s) & Examples \\
\hline \multirow[t]{2}{*}{ Pre-koine } & Immigration & $\begin{array}{l}\text { Ibanic-speaking groups began to migrate to } \\
\text { the upper watershed of the Batang Lupar } \\
\text { (Sarawak) in the sixteenth century (Sandin } \\
\text { 1968; Pringle 1970; Padoch 1982). }\end{array}$ \\
\hline & $\begin{array}{l}\text { Inter-variety } \\
\text { contact }\end{array}$ & $\begin{array}{l}\text { The present of Ibanic speakers, other than Iban } \\
\text { in Sarawak, for example: } \\
\text { - } \quad \text { the Remun in the Serian area (Cullip 2000; } \\
\text { - Chong and Remmy 2019); } \\
\text { the Balau along the Sadong River (Padoch } \\
\text { 1982; Sutlive 1992); } \\
\text { - the Milikin in the Serian area (Pringle 1970); } \\
\text { several Iban households from the Kantu' } \\
\text { district (Padoch 1982); } \\
\text { the presence of the Kumpang tribe in } \\
\text { Engkilili (Pringle 1970); and, } \\
\text { the Sebuyau in Lundu originating from the } \\
\text { Kapuas Basin (S.J. Anonby 2020). }\end{array}$ \\
\hline \multirow[t]{2}{*}{ Stabilization } & $\begin{array}{l}\text { Emergence of new } \\
\text { compromise sub- } \\
\text { system }\end{array}$ & $\begin{array}{l}\text { The variant with the phoneme of } / \mathrm{r} / \text { is selected } \\
\text { by two Iban strangers in conversation (Remmy } \\
2018 \text { ), for example, [biruw] 'blue' instead of } \\
\text { [bihu] or [biyu]. In addition, }<\mathrm{r}>\text { is selected as } \\
\text { the standard alphabet in Iban written system. }\end{array}$ \\
\hline & $\begin{array}{l}\text { Standardization } \\
\text { and/or literary } \\
\text { used of stabilized } \\
\text { koine }\end{array}$ & $\begin{array}{l}\text { - Standardized Iban (Jaku Iban Standard) is } \\
\text { used in radio broadcasting, law courts, } \\
\text { certain government agencies, and literary } \\
\text { discourses (Janang anak Ensiring 2005); see } \\
\text { Illustration 1. } \\
\text { A standard spelling system has been } \\
\text { developed. Through the efforts of } \\
\text { Christian missionaries, the Latin alphabet } \\
\text { was adopted into an Iban writing system } \\
\text { and widely used in Bible translations } \\
\text { (Asmah 1981). } \\
\text { Scholars produced dictionaries (A.J.N. } \\
\text { Richards 1988; Sutlive 1994) and grammars } \\
\text { and language manuals (O. Steinmayer } \\
\text { 1999). } \\
\text { Standard Iban is taught in primary and } \\
\text { secondary schools, alongside the National } \\
\text { Language (Bahasa Melayu). }\end{array}$ \\
\hline Nativization & $\begin{array}{l}\text { Become the first } \\
\text { language for a } \\
\text { group of speakers. }\end{array}$ & $\begin{array}{l}\text { In Sarawak, there are approximately 610,000 } \\
\text { native speakers of Iban and tens of thousands } \\
\text { second-language users (Janang 2005). Iban } \\
\text { is the lingua franca in Sarawak, especially in } \\
\text { upriver townships such as Betong, Kapit, Song, } \\
\text { and Kanowit (Mohammed Azlan Mis 2010). }\end{array}$ \\
\hline
\end{tabular}

Table 8. The matching of Iban language in the koine developmental continua. 


\section{TUJU}

DKSSP ditusun dikena narak nembiak ngambika sida ngembuan pengelandik bekomunikasyen ngena jaku lban standard dalam mayuh bengkah konteks beseriran enggau tikas pemansang lalu ulih neruska waris daya idup bansa lban sereta ngembuan semengat patriotisme ke bepelasar ba ukur pemanah dikena ngangkatka pengangkun ngagai jaku, menua enggau bansa.

\section{OBJEKTIF}

Sepenembu belajar ba primari enam nembiak patut/ ulih:

i. Ngembuan pengelanchar bekomunikasyen ba situasyen formal enggau enda formal.

ii. Macha mayuh bengkah teks nyengkaum teks kreatif dikena ngulihka penerang.

iii. Ngemeranka pengerindu macha, landik beperagam sereta nemu napis isi ke beguna.

iv. Nulis mayuh bansa karang ngena gaya jaku ti betul, entap sereta engkeman.

v. Ngemeranka jalai jaku enggau betul, entap sereta engkeman nitihka konteks.

vi. Ngemeranka ukur pemanah sereta ngena jaku lban standard lebuh berandau enggau betulis.

vii. Ngemeranka pengelandik bungai jaku lalu neruska waris daya idup dikena ngenegapka kaul antara raban bansa.

\section{DOKUMEN KURIKULUM STANDARD}

DKSSP tu ngundan Kurikulum, Standard Isi enggau Standard Pelajar. Standard Isi ngaraka standard minimum penemu, pengelandik enggau peneleba ti patut dikembuan nembiak sepenembu sida belajar ba sekula primari. Standard pelajar nya ngayanka tikas penemu, peneleba enggau pengelandik tauka tingkat profisiensi ti patut dikembuan nembiak ba setiap peringkat tauka kelas ba sekula primari.

\section{Translation}

\section{AIMS}

DKSSP (Dokumen Kurikulum, Standard Isi enggau Standard Pelajar or Standard-based Curriculum Framework) aims to equip pupils with excellent communication skills using the Standardized Iban Language in a variety of contexts in line with the country's rapid progress and development. At the same time, it also aims to enable pupils to preserve the Iban heritage and lifestyle, and possess a sense of solidarity and patriotism in upholding the pride of the Iban language, nation and race.

\section{OBJECTIVES}

By the end of Year 6, pupils should be able to:

i. communicate with peers and adults confidently and appropriately in formal and informal situations;

ii. read and comprehend a range of Iban texts including creative texts for information and enjoyment;

iii. appreciate and demonstrate a love of reading Iban literature or creative works for enjoyment; possess skills in prediction and an ability to scan for specific details;

iv. write a range of texts using appropriate language, style and form;

v. use correct and appropriate rules of grammar in speech and writing based on context;

vi. use correct and appropriate rules of Standardized Iban in speech and writing;

vii. use correct and appropriate idiomatic expressions, and preserve the Iban heritage and lifestyle so as to maintain unity among a multi-racial nation.

\section{STANDARD-BASED CURRICULUM FRAMEWORK}

DKSSP encompass the Curriculum, Content Standards and Learning Standards. The Content Standards is composed of specific statements about what pupils should know, understand and be able to do throughout their primary education. The Learning Standards are concise educational objectives which pupils are expected to know and be able to do at a particular stage of their primary education.

Illustration 1. An example of Standardized Iban. (Source: https:/ /www.moe.gov. my/menumedia/media-cetak/penerbitan/dskp-kssr/1254-dskp-kssr-bahasa-ibantahun-6/file. Page 7). 


\subsection{Phonological distillations}

This sub-section explores the phonological distillations of various subsystems which came into contact and how a new compromise sub-system has emerged. The result of distillation is often reduced in complexity compared to the contributing sub-systems (Siegel 1985). The process of levelling and simplification will be discussed in this sub-section, whereas mixing is exempted since this process simply involves the presence of features from different input varieties; see Kerswill (2013).

Levelling is the process of reduction in structural variation or the reduction or attrition of marked variants. "Marked" here might refer to features which have a limited geographical distribution in the country of origin; see Trudgill (1986). The term simplification can be taken to refer to 'an increase in regularity' in a language and should be used only relatively with reference to the source language (Trudgill 1983). If the Iban variant in Sarawak is hypothesized as a koine language, there should be some evidence of attrition of several marked features in the Ibanic variants spoken in their homeland, for example, the Ketungau, Kantu', Mualang, et cetera.

\subsection{THE VARIATIONS OF / $\mathrm{r} /$}

Based on recent studies, the Ibanic varieties in West Kalimantan are diverse in their reflections of Proto-Malayic * $\mathrm{z}$ :

(a) [x] in Seberuang and Desa (Examples: [xa:y] 'jaw' and [uxyay]);

(b) [y] in Remun, Kumpang, Kantu', Desa (Examples: [yumeah] 'house' and [gayam] 'salt');

(с) [в] in Mualang, Sebaru', and Sekujam (Examples: [ва:п] 'understand', [dаваh] 'blood');

(d) [h] in the Iban variant of Sibu and Samarahan (Sarawak); and,

(e) [r] in the Iban variety in Danau Kapuas and in Sarawak elsewhere, with the exception of Sibu and Samarahan.

Although the allophonic situation of / $\mathrm{r}$ / is rather complex, Ibanic informants are aware that the allophones $[\mathrm{\gamma}],[\mathrm{b}]$, or $[\mathrm{x}]$ correspond to $/ \mathrm{r} /$ in bahasa Indonesia.

In Sarawak, <r> was chosen as the literacy alphabet in Bible translations by Christian missionaries, printed media, educational books, and broadcasting. In daily communication, Chong (2010) reports that the Iban speakers from different backgrounds accommodate one another in their speech. This accommodation includes phonological alternations, code-mixing, and code-switching. Through simplification, allophones like $[\mathrm{x}],[\mathrm{\gamma}]$, or $[\mathrm{r}]$ can alternate with $[\mathrm{r}]-$ as this sound is widely pronounced in literacy and formal communication. ${ }^{3}$

\footnotetext{
${ }^{3}$ A similar case of / $\mathrm{r}$ / replacement is mentioned in J.K. Chambers and P. Trudgill (1998). In the koine languages of Tyssedal and Odda, Norway, which both have the uvular [в] for $/ \mathrm{r} /$, a pronunciation has been diffusing outwards from the towns throughout the west and south of Norway for the past 100 years, replacing an alveolar articulation.
} 


\subsection{THE ALLOPHONES OF /-s/}

The /s/ in word-final position in the Ibanic varieties of Kalimantan exhibits various allophones, for example, a fricative aveolar [s] in Mualang, a fricative palatal [ç] in Seberuang, a fricative glottal [h] in Demam, Sebaru', and Iban (both near Kapuas Lake and Sarawak), see Table 9.

\begin{tabular}{|c|c|c|c|}
\hline \multicolumn{2}{|l|}{ Ibanic varieties } & Allophones & 'sweet', 'hot', 'fracture' \\
\hline \multicolumn{2}{|l|}{ Demam } & Ç & manieç, panayç, putuyç \\
\hline \multicolumn{2}{|l|}{ Sebaru' } & ç & manieç, panayç, putuyç \\
\hline \multicolumn{2}{|l|}{ Seberuang } & Ç & manieç, panayç, putuyç \\
\hline \multicolumn{2}{|l|}{ Banjur } & ç & manieç, panayç, putuyç \\
\hline \multicolumn{2}{|l|}{ Bugau } & $\mathrm{h}$ & manieh, panayh, putuyh \\
\hline \multicolumn{2}{|l|}{ Mualang } & $\mathrm{s}$ & manies, panas, putus \\
\hline \multicolumn{2}{|l|}{ Kantu' } & $\mathrm{h}$ & maniyh, NO DATA, putuyh \\
\hline \multirow[t]{2}{*}{ Iban (Sentarum Lake) } & Keladan & $\mathrm{h}$ & maniyh, NO DATA, putuyh \\
\hline & Kelawe' & $\mathrm{h}$ & maniyh, NO DATA, putuyh \\
\hline \multirow[t]{2}{*}{ Iban (Sarawak) } & Samarahan & $\mathrm{h}$ & maniyh, NO DATA, putuyh \\
\hline & Lundu & $\mathrm{h}$ & maniyh, NO DATA, putuyh \\
\hline
\end{tabular}

Table 9. The allophones of /-s/ in Ibanic varieties.

Because of the articulatory position of [ç] and [h], I assume that these fricative voiceless vowels can be shifted alternately. A similar case can be found in the Kedah Malay dialect. The allophones of /s/ in the word-final position have been analysed in different ways. Collins (1986) records that [ç] is the allophone of /s/ in Kedah Malay dialect, whereas Ismail Dahaman et al. (1997) list [-h], [-eh], and [éh] as allophones of /-s/ in this dialect. In the Standard Iban writing system in Sarawak, the selection of $<\mathrm{s}>$ rather than the expected $<\mathrm{h}>$ is to distinguish this phoneme from a historical word-final $/ \mathrm{h} /$, for example, in yumeah 'house' and saleah 'wrong'.

\subsection{VOWEL RAISING}

The centralization of final high vowels is very common in the Ketungau Sesat variety, for example, sikuw 'elbow' and kakiy 'leg'. As mentioned earlier, most Ibanic varieties (including those of Sarawak) display the high vowels $[u, i]$ in the final syllable. This high vowel raising process posits $/ \mathfrak{u}, \dot{i} /$ as the default phoneme in a closed syllable final position of the stem. ${ }^{4}$ Under the levelling process, the rule of vowel raising can be formulated as follows.

4 According to Teoh Boon Seong (1994), /i, u, a/ are more natural phonemicizations than midvowels across languages. This asymmetry between mid- and high vowels is usually attributed to the fact that $[\mathrm{i}, \mathrm{u}, \mathrm{o}]$ distribute the vowels more widely across acoustics space than do [e, o, a]. There are some cases in which the "more complex" mid-vowels are excluded, for example, the Yaka language, in which the mid-vowels are barred from suffixes. 


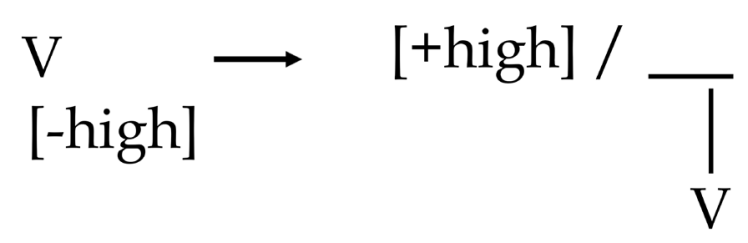

\subsection{The DiPHTONG OF / -ay/}

As noted in Hudson (1970), the diphthong / ay/ in Ibanic variants is an innovation from PM *an. This historical element is reflected as follows:

(a) The Ketungau Sesat variety exhibits a weakening of the final velar nasal $/ \mathrm{y} /$, which is retained only as the nasalization of the preceding

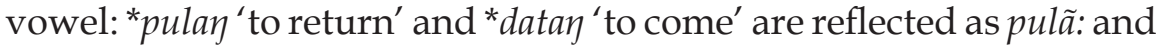
datã: respectively. On the other hand, Ibanic variants such as Mualang, Bugau, Seberuang, Kumpang, and Desa display the segment as /-ay/: pulay and datay.

(b) Nanga Skepat (a Demam variety) displays vowel insertion [-a $\left.\mathrm{a}^{\mathrm{e}} \mathrm{y}\right]$ in reflexes of PM *an, for example, pula $y$ and data $y$.

(c) The Sebaru' variety along the Ketungau River exhibits reflexes of PM *-an as /-ey/, for example, puley and datey.

If we assume that /-ay/ used by the Iban of Sarawak is a simplified form of a regional dialect levelling, we can postulate that an "increase of regularity" took place in the diphthongs mentioned above. For example, the co-articulation features in pula $y$ and data ${ }^{e} y$ (Sebaru' variety) can be simplified by the deletion of [-e- $]$. The front-mid vowel diphthong / ey/ in Demam, in many cases, shows the alternation of /-ey/ /-ay/. The diphthong of [ay] in the Sarawak dialect of Malay and [ey] in Rejang dialect are reported to have parallel alternations, for example, in suyay sujey 'river' (Chong 2019).

\section{IBAN KOINEIZATION FROM HISTORICAL AND CONTEMPORARY PERSPECTIVES}

This section outlines some crucial historical and contemporary developments which exert a direct impact on my koineization theory of the Iban language in Sarawak. The historical migration of the Ibanic people is an established demographic fact. They settled in the Batang Lupar Valley and adjacent areas before the Brooke era. Their dispersal to other river systems (for example, to Rejang, Mukah, Kemena, and the Baram Valley) under Brooke rule created political difficulties in Sarawak, not least the threat that they could outnumber pre-existing tribes and have a detrimental environmental effect on lands intended for shifting cultivation. Hence, the "Iban" were restricted by the government from further migration to other river systems. The struggle between the Brooke government and the "Iban" about their settlement in the Balleh Valley (Sutlive 1992) illustrates these tensions. 
Although these migrations posed problems for the Brookes (Pringle 2007), they also presented opportunities. Since the "Ibanic speakers" were perceived to be recognized, energetic, experienced, and assiduous pioneers, they were encouraged by the Brooke government to travel through new districts in search of wild rubber, rattans, camphor, damar, and other jungle products. The government also promoted permanent "Iban" settlements in some of the newly ceded areas. After the seizure of Limbang in 1890, in order to consolidate their authority in other new northeastern provinces, the Sarawak Government relied upon the "Iban" to bolster its authority. "Iban" settlers were imported by Rajah Brooke to help him maintain order in Baram. In the late nineteenth century, Batang Ai, Batang Lupar, and the Skrang Valley became overpopulated. With certain restrictions, the Brooke government opened up additional areas to the "Iban" settlement. For example, Brooke allowed the "Iban" in Simanggang unrestricted migration to Balingian, Bintulu, and Baram for some time; around 1900, the "Iban" in the Second Division of Sarawak were granted permission to migrate to Limbang and the government also sponsored the migration of "Ibans" from Batang Lupar to Lundu. This policy of encouragement eventually accelerated the expansion of the Iban language throughout the state.

Successful occupation and the government sponsorship of immigration have both left an impact on other communities native to Sarawak. The Bukitans along the middle and lower Batang Lupar, for example, were reported to have been totally assimilated into the Iban community. When the Bukitan leaders intermarried with the Ibans, whole Bukitan communities gradually adopted the Iban language and farming methods, thereby becoming Ibans themselves (Pringle 2007). Hence, assimilation and identity shifts of minority tribes contributed to the growth of the Iban population in Sarawak.

In present-day Sarawak, several state and national agencies are also playing crucial roles in the so-called stabilization stage of koine development. As noted in Siegel (1985: 376), in this stage, "the koine language becomes literary language and standard language". Janang (2005) has listed seven agencies involved with the standardization of Iban as the literary language (Table 10). 


\begin{tabular}{|l|l|}
\hline Agencies & Roles \\
\hline 1. Tun Jugah Foundation & $\begin{array}{l}\text { Promoting Iban culture, arts, and } \\
\text { language } \\
\text { Conducting research and providing } \\
\text { intellectual materials and } \\
\text { educational tools } \\
\text { Documentations of Iban folklore } \\
\text { Compiling and publishing Iban } \\
\text { dictionaries }\end{array}$ \\
\hline 2. Ministry of Education & $\begin{array}{l}\text { Consulting on Standardized Iban } \\
\text { Implementing Iban as a subject in } \\
\text { the Sarawak school curriculum }\end{array}$ \\
\hline Formulating syllabuses and teacher \\
guides for Iban
\end{tabular}

Table 10. The agencies participated in the development of Iban language in Sarawak.

\section{CONCLUSION}

This article argues that, as a result of the shifting of the term "Iban" from exonym to endonym in Sarawak, plus the linguistic homogeny of Iban throughout the state, existing theories which postulate that the present Iban community in Sarawak was formed by the migration of ethnic Ibans from West Kalimantan, Indonesia, are inaccurate. Current research in West Kalimantan has revealed that this area is diverse and complex in terms of Ibanic varieties and terminologies. Yet the number of Ibans in West Kalimantan, claimed by previous scholars to have strongly influenced Sarawak's demographic profile, is small and confined to the Kapuas Lake area. We must therefore provide a rational explanation of how the Iban community in Sarawak could have been formed through the migration of this minority ethnic group. By tracing the reports about the emergence of other Ibanic groups in Sarawak and the process of language koineization, this study has demonstrated that the Iban language in Sarawak fulfils all three stages of the koine developmental continuum. 
Furthermore, linguistic analysis on the Ibanic data in West Kalimantan shows that the marked phonological features in Ibanic variants have probably been levelled or simplified through the process of koineization. This situation resembles that of South Africa's Bhojpuri koine (Mesthrie 1993) and Fiji's Hindustani koine (see Siegel 1987). The hope is that this article's pioneering engagement in koine research in the context of Southeast Asia will inspire and contribute new knowledge to minority and diaspora studies in this part of the world.

\section{REFERENCES}

Adelaar, K.A. 1992. Proto-Malayic; The reconstruction of its phonology and parts of its lexicon and morphology. Canberra: Australian National University. [Pacific Linguistics C 119.]

Amery, R. 1993. “An Australian koine; Dhuwana, a variety of Yolngu Matha spoken at Yirrkala in Northeast Arnhem land", International Journal of the Sociology of Language 99: 45-64.

Anonby, S.J. 2020. Prolonged multilingualism among the Sebuyau; An ethnography of communication. PhD thesis, Simon Fraser University, Burnaby, Canada. Asmah Haji Omar. 1981. The Iban language of Sarawak; A grammatical description. Kuala Lumpur: Dewan Bahasa dan Pustaka.

Blanc, H. 1968. "The Israeli koine as an emergent national standard", in: Joshua A. Fishman, Charles A. Ferguson, and Jyotirindra Das Gupta (eds), Language problems of developing nations, pp. 237-251. London/New York, NY: Wiley.

Bubenik, V. 1993. “Dialect contact and koineization; The case of Hellenistic Greek", International Journal of the Sociology of Language 99: 9-23.

Chambers, J.K. and P. Trudgill. 1998. Dialectology. Cambridge: Cambridge University Press.

Chong Shin and James T. Collins. 2019. Bahasa dan masyarakat di Lembangan Sungai Saribas. Kuala Lumpur: Dewan Bahasa dan Pustaka.

Chong Shin and Remmy anak Gedat. 2019. “Bahasa Remun di negeri Sarawak; Kajian perbandingan dengan bahasa Iban", GEMA Online; Journal of Language Studies 19(4): 203-218.

Chong Shin. 2008. “Kepelbagaian varian Ibanik: Tinjauan di Sungai Ketungau dan Belitang, Kalimantan Barat", Bahasa 13 (Januari-April): 45-58.

Chong Shin. 2010. "Akomodasi pertuturan dan bahasa Iban ke bahasa Iban", Bahasa 19: 104-112.

Chong Shin. 2019. Bahasa Ibanik di Borneo Barat. Kuala Lumpur: Dewan Bahasa dan Pustaka.

Collins, James T. 1986. Antologi kajian dialek Melayu. Kuala Lumpur: Dewan Bahasa dan Pustaka.

Collins, James T. 2002. "Bahasa dan etnisiti di Pulau Borneo; Tinjauan awal di Kalimantan Barat", Dewan Bahasa 2(4): 29-35.

Collins, James T. 2004. "Ibanic languages in Kalimantan Barat, Indonesia; Exploring nomenclature, distribution, and characteristics", Borneo Research Bulletin 35: 17-47. 
Cullip, Peter H. 2000. "Language use and attitudes of the Remun of Sarawak", Sarawak Museum Journal Vol. LV No. 76 (New Series): 1-44.

Dahaman, Ismail et al. 1997. Glosari dialek Kedah. Kuala Lumpur: Dewan Bahasa dan Pustaka.

Dove, Michael R. 1988. "The ecology of intoxication among the Kantu' of West Kalimantan", in: Michael Dove (ed.), The real and imagined role of culture in development; Case studies from Indonesia, pp. 139-182. Honolulu, HI: University of Hawaii Press.

Dunselman, P.D. 1955. Kana Sera, zang der zwangerschap. Leiden: Brill.

Enthoven, J.J.K . 1903. Bijdragen tot de geographie van Borneo's Westerafdeeling. 2 vols. Leiden: Brill.

Heppell, M. 2020. "Iban beaded costume". [Retrieved from: https://www. artoftheancestors.com/blog/iban-beaded-costume-michael-heppell; accessed on 14-10-2020.]

Hose, C. and W. McDougall. 1966. The Pagan tribes of Borneo. London: McMillan. Hudson, A.B. 1970. "A note on Selako; Malayic Dayak and Land Dayak language in Western Borneo", Sarawak Museum Journal Vol. XVIII No. 36-37: 301-318.

Janang anak Ensiring. 2005. “Bup Jako Iban (Iban Wordbook)”, in: James T. Collins and Hermansyah (eds), The languages and literatures of Western Borneo; 144 years of research, pp. 190-202. Bangi: Institut Alam dan Tamadun Melayu.

Kerswill, P. 2002. "Koineization and accommodation”, in: J.K. Chambers and Natalie Schilling (eds), The handbook of language variation and change, pp. 669-702. Oxford: Blackwell.

Kerswill, P. 2013. “Koinezation”, in: J. K. Chambers and Natalie Schilling (eds), The handbook of language variation and change, pp. 519-536. New Jersey, NJ: John Wiley. [Second edition.]

Kerswill, P. and A. Williams. 2005. "New towns and koinezation; Linguistics and social correlates", Linguistics 43(5): 1023-1048.

King, V. 1976. "Some aspects of Iban-Maloh contact in West Kalimantan", Indonesia 21(April): 85-114.

King, V. 1978. "The Mualang of Indonesian Borneo; Neglected sources for Iban studies", Borneo Research Bulletin 10(2): 57-72.

Mesthrie, R. 1993. "Koinezation in Bhojpuri-Hindi diaspore-with special reference to South Africa", International Journal of the Sociology of Language 99: $25-44$.

Mohammed Azlan Mis. 2010. “Lingua franca di Sarawak; Aplikasi teori pemilihan bahasa", GEMA Online; Journal of Languages Studies 10(2): 97-116.

Padang anak Luna and Chemaline anak Osup. 2011. Sintaksis Iban; Malin nembiak enggau pengajar. Tanjong Malim: Emeritus Publications.

Padoch, C. 1982. Migration and its alternatives among the Iban of Sarawak. The Hague: Martinus Nijhoff.

Pringle, R. 1970. Rajahs and rebels; The Iban of Sarawak under Brooke rule. Ithaca, NY: Cornell University Press. 
Pringle, R. 2007. Rajahs and rebels; The Ibans of Sarawak under Brooke rule. Kuala Lumpur: Abdul Majeed. [Reprinted.]

Rahim Aman. 1997. “Perbandingan fonologi dan morfologi bahasa Iban, Kantuk dan Mualang". MA thesis, Universiti Kebangsaan Malaysia.

Rahim Aman. 2006. Perbandingan fonologi dan morfologi bahasa Iban, Kantuk dan Mualang. Kuala Lumpur: Dewan Bahasa dan Pustaka.

Ray, J.J. 1913. "The languages of Borneo", The Sarawak Museum Journal 1(4): 1-196.

Remmy anak Gedat. 2018. Variasi bahasa Iban dalam berkomunikasi. Kuala Lumpur: Dewan Bahasa dan Pustaka.

Richards, A.J.N. 1988. An Iban-English dictionary. Kuala Lumpur: Penerbit Fajar Bakti.

Sandin, B. 1968. The Sea Dayaks of Borneo before White Rajah rule. East Lansing, MI: Michigan State University Press.

Sather, C. 2016. "The sugi sakit; Ritual storytelling in a Saribas Iban rite of healing", Wacana, Journal of the Humanities of Indonesia Vol. 17 No. 2: 251-277.

Siegel, J. 1985. "Koines and koineization", Language in Society 14(3): 357-378.

Siegel, J. 1987. Language contact in plantation environment; A sociolinguistic history of Fiji. Cambridge: Cambridge University Press.

Siegel, J. 1993. "Introduction; Controversies in the study of koines and koinezation", International Journal of the Sociology of Language, pp. 5-8. Berlin: Mouton de Gruyter.

Smith, A.D. 2017. The languages of Borneo; A comprehensive classification. $\mathrm{PhD}$ thesis, University of Hawai'i.

Spence, J.D. 2013. Language change, contact, and koineization in Pacific Coast Athabaskan. PhD thesis, University of California, Berkeley.

Steinmayer, O. 1999. Jalai Jako' lban; A basic grammar of the Iban language of Sarawak. Kuching, Sarawak: Klasik Publishing House.

Sutlive, V.H. 1992. Tun Jugah; Colonialism and Iban response. Kuching, Sarawak: Sarawak Literacy Society.

Sutlive, V.H. 1994. A handy reference dictionary of Iban and English. Kuching, Sarawak: Tun Jugah Foundation.

Teoh Boon Seong. 1994. The sound system of Malay revisited. Kuala Lumpur: Dewan Bahasa dan Pustaka.

Thompson, G. 1960. The Greek language. Cambridge: W. Heffer.

Tjia, J. 2007. A grammar of Mualang; An Ibanic language of Western Kalimantan. $\mathrm{PhD}$ thesis, Universiteit Leiden.

Trudgill, P. 1983. On dialect; Social and geographical perspectives. New York, NY: New York University Press.

Trudgill, P. 1986. Dialects in contact. Oxford: Blackwell.

Wadley, Reed. 1994. "A brief look at Iban humor", Suvannabhumi 6(1): 8-9.

Yoseph Thomas et al. 1992. Struktur bahasa Kantuk. Jakarta: Pusat Pembinaan dan Pengembangan Bahasa.

Yusriadi. 2019. "Bahasa Kantuk di Tanah leluhur; Laporan dari Selupai", in: Chong Shin (ed.), Bahasa Ibanik di Borneo Barat, pp. 88-99. Kuala Lumpur: Dewan Bahasa dan Pustaka. 